\title{
ISOLATION OF HEART AND CARDIOGENIC PRIMORDIUM FROM EARLY JAPANESE QUAIL EMBRYOS FOR RNA AND GENE EXPRESSION STUDY
}

\author{
O. M. ANDRISANI, A. R. IRIZARRY, S. K. WOLFE, J. C. VELLINGER ${ }^{1}$, R. L. HULLINGER.
}

Department of Basic Medical Sciences, School of Veterinary Medicine, Purdue University, West Lafayette, IN 47907, USA ${ }^{1}$ Space Hardware Optimization Technology, Inc., Floyd Knobs, IN 47119, USA

Received April 18, 1995

Accepted June 6, 1996

\begin{abstract}
Andrisani, O. M., A. R. Irizarry, S. K. Wolfe, J. C. Vellinger, R. L. Hullinger: Isolation of Heart and Cardiogenic Primordium from Early Japanese Quail Embryos for RNA and Gene Expression Study. Acta vet. Brno 1996, 65: 51-56.

We have successfully and reproducibly isolated total RNA from small amounts of Japanese quail cardiac tissue (sample size of 5-25 embryonic hearts), employing the Triozol method for RNA preparation. We have isolated RNA from the embryonic heart of approximately 150 quail embryos, at different stages of myocardiogenesis, including 8-14 somite stages, 15-19 somite stages, and 20-34 somite stages. We have also isolated the cardiogenic primordium from 2-8 somite stages.

In addition, we isolated myocardial RNA from approximately 400 Japanese quail embryos of the hypodynamy-selected Ivanka OI strain of Japanese quail (Institute of Animal Biochemistry and Genetics, Slovak Academy Sciences). Specifically, we obtained total RNA from embryonic hearts of approximately 100 Japanese quail embryos from each of these stages: 8-14 somites, 15-19 somites, and $20-34$ somites.

We have developed these isolation procedures in support of our investigations of avian heart development. The aim of this work is to examine the effect of gravity (hypergravity and $1 \mathrm{~g}$ ) on the expression pattern of specific groups of genes, in the embryonic heart of developing chick and quail embryos. Based on these results we will formulate a cellular and molecular biologic model of how the developing cardiac myocyte senses and responds to gravity and changed load application during its development.
\end{abstract}

$R N A$, myocardium, hemodynamic pressure, isolation methods

The embryos of domesticated chicks (Gallus domesticus) and Japanese quail (Coturnix coturnix japonica) do not tolerate well incubation during days 1-7 in the microgravity of low orbital space flight. As the cardiovascular system undergoes critical development to reach a functional state in this incubation period, our goal has become the examination of the gene expression pattern of select, developmentally regulated genes in avian myocardial cells when exposed to altered gravitational force. Our hypothesis is that gene expression will be changed under these altered gravity conditions and altered in a way detrimental to the embryo.

Results from STS-29 Shuttle. Two groups of chicken embryos (Gallus domesticus) 2-d and 9-d incubation stage at launch) were flown in 1989 on the STS-29 Shuttle for a 5-d mission (Hulling er 1993a). The embryos demonstrated an age-dependent and markedly different response to their microgravity exposure. None of the sixteen 2-d embryos survived the 5 day incubation in low-earth orbit. All sixteen for the 9-d embryos and all ground controls of both age groups survived the 5-d mission and eventually hatched at $21 \mathrm{~d}$. All 2-d embryos died while incubating in orbit, but at different ages/stages (Table 1). By mesoscopic examination and analysis these embryos (2-d group) appeared normally formed for their age and stage (Fig. 1). The variation in their response to the microgravity environment (i. e., variation in their age at death) was assumed to be due to: 1) slight but undetermined differences in their stage of development at launch and entry into 
Table 1

Shuttle STS-29 2-d Chick Embryo Mortality

$\begin{array}{cc}\text { AGE IN DAYS } & \text { STRUCTURE OR } \\ \text { AT DEATH } & \text { \# SOMITES* } \\ 7 & -. \\ 6.5 & \text { knee } \\ 6 & \text { elbow } \\ 5.5 & 4 \text { toes } \\ 5 & 2 \text { toes } \\ 4.5 & \text { wing plate } \\ 4 & \text { toe plate } \\ 3.5 & 43-44 \\ 3 & 37-40 \\ 2.5 & 29-30 \\ 2 & 19 \\ \text { no embryos** } & \text { membranes }\end{array}$

STAGE \#**
31
30
29
28
27
25
24
21
19
17
13
unknown

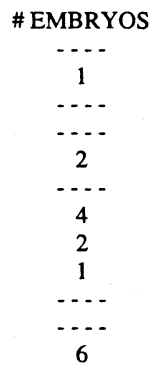

* Hamburger and Hamilton (1951).

** Eggs revealing no embryos showed evidence of extraembryonic membranes.

microgravity, 2) individual response differences to microgravity environment, or 3) a combination of both. A discussion of the various causal possibilities and the variation of age/stage at death has been discussed elsewhere (Hulling er 1993b).

All 2-d chick embryos on the STS-29 mission were $48 \mathrm{~h}( \pm 4 \mathrm{~h}$, estimated) at launch. By this stage, the developing heart tube is functioning, although not fully developed. As the cardiovascular system continues this structural/functional differentiation, any adverse effects of microgravity may also affect the developing heart. For this reason we are investigating the pattern of gene expression in cardiac myocytes during this early developmental period.

Furthermore, our results have been confirmed by the results from Spacelab J, STS-47 flown in 1992 (ASGSB, 1993). Thirty chicken embryos of two different age groups were incubated during a short orbital flight. The experimental design included periodic rotation of the eggs while in microgravity. Only one of the younger embryos survived while all but one of the older embryos survived until hatch.

Japanese quail incubating in space flight. The mortality results for young chick embryos of our STS-29 flight support those for the Japanese quail (Coturnix coturnix japonica) flown on Incubator I of Cosmos 1129 in 1979 (S a b o 1980) and Incubator 2A in 1990 (Meleshko et al. 1991; Gurye va et al. 1993). In the first flight experiment 39 fertile eggs were incubated for the 11.5-d mission, beginning embryo age 1d. Of these, 22/39 stopped developing during days $1-4,4 / 39$ during days $5-9$, and 13 during days 9-11.5. However, $3 / 39$ had developed until mission's end at $11.5 \mathrm{~d}$. In the 1990 experiment, 8/33 quail embryos completed development and 6 pipped and hatched in orbit. The age/stage of the remaining 25 embryos was not determined. This evidence suggests that for Japanese quail the critical period of development is, like in the domesticated chick studies, in the first days, i. e., days of cardiovascular development.

Myocardial Gene Expression. It is now possible to follow differentiation of the cardiac myocyte by measuring the expression of a developmentally regulated set of gene families (Swynghedaun 1986). The plasticity of the adult or embryonic contractile protein gene expression in the myocyte has been shown to be influenced by hemodynamics and pressure load (e. g., Komuro and Yazaki 1993). During embryonic/fetal development, morphogenesis of the cardiovascular system relies upon cell proliferation, migration, histogenesis, and definitive cellular differentiation. The sequence of these events 
is tightly regulated and of great importance for normal development of the heart. The expression, synthesis, and activity of key regulator gene products determine cell proliferation, migration, and determine the phenotype of cardiac myocytes comprising the myocardium. Aberrations in these processes or their regulation may lead to death of the embryo (see preliminary results from STS-29, STS-47, and Incubator I above) or severe congenital birth/hatch defects. Presently the effect of microgravity on this expression in the developing heart is not known; our goal is to investigate this effect by examining the expression of three select classes of developmentally regulated genes in the avian heart.

Avian embryos represent a developmental model with several advantages over their viviparous counterparts. They can be individually manipulated; they contain all nutriments and growth factors for development until hatch; and they are unaffected by a maternal host response to the experimental environment. Recognizing these advantages, we document our method of isolation of this most important of the early organs to develop to a functional status, the heart.

\section{Materials, Methods and Results}

The studies of avian development in microgravity in our laboratory are now linked in a collaborative effort with colleagues of the Slovak Academy of Sciences, Ivanka pri Dunaji, Slovakia and the Institute of Biomedical Problems, Moscow, Russia. The methods we report upon herein utilized the quail, many of which are from the Ivanka 01 strain.

Is olation of quail e mbryos. The egg shell was opened above the air sac, at the base (broad end) of the egg. Prior to about 20 somites, most embryos lie lateral to the margin of the air sac. These embryos can be brought to a position dorsal to the yolk by gently pulling the membranes with forceps. For embryos younger than 20 somites, we found it best to work with the embryos in this dorsal position and a large opening in the shell to expose the embryo (Figures 2A, 2B). Embryos older than 20 somites, but less than 40 somites, are often best isolated in a petri dish kept chilled on ice (Figures 3A, 3B). (The most reliable method for embryo staging is the number of developed somites, versus hours of egg/embryo incubation. At $12 \mathrm{~h}, 18 \mathrm{~h}$, and $24 \mathrm{~h}$ there is variation in somite numbers, often a variation of 5 or 6 pairs. We conclude that somite numbers will also indicate the cell and tissue differentiation elsewhere in the embryo and do so more reliably than hours of incubation.)

To pick up the embryos until about three days of age, we find most reliable the use of glass microfiber filter papers (Whatman 934-AH, Whatman International, Maidstone, England) with a $1 \mathrm{~cm}$ aperture hand cut in each. These ,donut" rings are placed over the embryo, which can be positioned in the center of the aperture, and the protein of the egg membrane guickly adheres and fixes to the filter.

With curved forceps the filter ring is gently elevated at one point and the membrane is cut with scissors. This incision is entended around the perimeter of the ring. This frees the ring from the egg. The embryo remains suspended across the aperture and is then transferred directly to a cold petri dish. A jet of chilled saline from a syringe with an 18 gauge needle may now be used to flush yolk droplets from beneath the embryo.

For embryos 20-40 somites (approx. 2-3 days) it is often easier to pour the egg contents into the petri dish and repeat the embryo isolation and ring pick-up method while keeping the dish on ice (Figures 3C, 3D).

Embryos older than 40 somites can be easily isolated with forceps while in the opened egg and directly transferred to a petri dish.

The chilled embryo, younger ones still in the filter ring, are viewed under a dissection microscope (Wild Harburgg M7A) equipped with Intralux Volpi fiber optics illuminator and 
a trinocular head with attached Nikon VN-550 Action 8 video camera. With the camera autofocus off, it is possible to document the embryo size (somite numbers) and, after 8 somites, easily document viability by the heart contractions. Using two corneal knives and microforceps, whole embryos can be dissected, and by opposed cutting with the knives, separated from their extraembryonic membranes and yolk.

By the same cutting procedure the heart, or, for those embryos younger than 8 somites, the cardiogenic primordium, can be isolated (Figures 3A-D, 4) and transferred directly to chilled guanidine hydrochloride for the RNA isolation procedure. The embryos can be easily fixed (chemical or physical) for morphologic analyses, e. g., light or electron microscopy (Figures 5, 6A-C); histochemical analyses; or in situ molecular biologic evaluation ( $\mathrm{S} \mathrm{u} \mathrm{g} \mathrm{i} \mathrm{et} \mathrm{al.}$ 1995). The RNA isolation procedure employs the TRIzol ${ }^{\mathrm{TM}}$ reagent (GIBCO, Bethesda Research Laboratories): which is a phenol/guanidine HC1-containing reagent. Total RNA is extracted following homogenization of tissue in the apporopriate volume of TRIzol ${ }^{\mathrm{TM}}$ and ethanol precipitation. Total RNA is precipitated by chloroform/isopropyl alcohol and centrifugation for 10 minutes. The integrity of the RNA is examined by agaroseformaldehyde gel electrophoresis (A u subel et al. 1994).

Briefly, the RNA to be analyzed is dissolved in buffer containing $2.2 \mathrm{M}$ formaldehyde and $50 \%$ formamide. Following treatment at $70{ }^{\circ} \mathrm{C}$ for 10 minutes, the RNA is loaded in a $1 \%$ agarose-formaldehyde gel; the final concentration of formaldehyde is $2.2 \mathrm{M}$ in the agarose gel. Electrophoresis is carried out in 1X MOPS-EDTA buffer (0.05 M MOPS, pH 7.0 with $0.001 \mathrm{M}$ EDTA, pH 7.5). The RNA is visualized by UV after ethidium bromide staining. The agarose gel is stained in $5 \mu \mathrm{g} / \mathrm{ml}$ ethidium bromide for 5 minutes and destained in water overnight (Figure 7).

\section{Discussion}

Our experimental system is the embryonic heart of the domecticated chicken and Japanese quail, at day 1-20 of development. The rationale for using this system is based on the availability of preliminary, space flight data for both the chick and quail strains. The chick embryos are of the Ross-Ross strain as used in our previous flight experiments ( $\mathrm{Hu} \mathrm{ll} \mathrm{in} \mathrm{ger}$ 1993b). The quail embryos are of a selected C. japonica strain (B od a et al. 1992) known as Ivanka 01 .

These birds present an intriguing model for the study of gene expression in the myocardium subjected to altered hemodynamic pressure and mechanical overload. So too, these birds are of interest as they are essentially a model for chronic bedrest effects.

We have demonstrated that we can identify and isolate the embryonic heart at these initial stages of development. Domesticated chicken and Japanese quail embryos reveal a consistent developmental pattern of structure (Hamburger and Hamilt on 1951; $\mathrm{Padget} t$ and I vey 1960). Thus, we are confident that the expertise we have developed in the isolation of quail embryonic heart will also apply for the system of the domesticated chicken.

RNA has been isolated, as described above, from embryonic cardiac tissue at day 1 through 5 of development. We will now study the expression pattern of the genes by employing the polymerase chain reaction, PCR (S a i ki et al. 1986). The question we will address by examining the expression of select immediate-early genes, is whether the conditions of hypo- and hypergravity will induce, in the avian embryo (chick and quail), the expression of genes normally expressed in the adult heart under conditions of mechanical/hemodynamic overload.

This research is designed to produce details of the differentiation of the myocardial cells, 
especially the specifics of gene expression as the cells progress from myoblast to definitive cardiac myocyte. This expression model will have application in understanding normal/abnormal development of the heart in other animals and man.

The model has developed as an extension of observations we have made in space flight gravitational biology. Notwithstanding the importance for astronaut adaption to space flight or habitation of the altered gravity of lunar or martian colonies, the greater significance of this research will be the application as a general model for heart development and adaptation. The model can be directly utilized to study changes in gene expression of the cardiac myocyte in growing, or adult birds, animals, or man in exercise/training and more importantly, in chronic bedrest.

\section{Acknowledgements}

We gratefully acknowledge the generous support of Space Hardware Optimization Technology, Inc., Floyd Knobs, IN for research fellowship support of Irizarry and Wolfe; NASA contracts NAS2-13908 and NAS2-14066; Drs. M. Juráni, K. Boda, and Ing. V. Sabo of the Slovak Academy of Sciences, Ivanka pri Dunaji, Slovakia, for embryos of the Ivanka 01 strain; and J. S. Williams for valuable technical assistance.

\section{Izolácia srdca a kardiogénneho primordia z včasných embryí japonskej prepelice pre štúdium RNK a génovej expresie}

Úspešne a reprodukovateIným spôsobom sme izolovali celkovú RNK z malých množstiev srdcového tkaniva embryí japonskej prepelice (jednotlivé vzorky boli z 5-25 embryí) $s$ použitím Triozolovej metódy na preparáciu RNK. Izolovali sme RNK z cca 150 embryí v rôznom štádiu vývoja myokardu, vrátane štádií 2-8, 8-14, 15-19 a 20-34 somitov.

Izolovali sme tiež RNK z myokardu asi 400 embryí japonskej prepelice kmeňa Ivanka 01, selektovaného na rezistenciu voči hypodynamii, a to v štádiu 8-14, 15-19 a 20-34 somitov. Tieto izolačné postupy sme vyvinuli pre štúdium vývoja aviárneho srdca. Cielom práce je sledovat vplyv gravitácie (hypergravitácie a $1 \mathrm{~g}$ ) na expresiu určitých skupín génov $\mathrm{v}$ embryonálnom srdci kurčiat a prepelíc. $\mathrm{Na}$ základe získaných výsledkov budeme s využitím celulárnej a molekulárnej biológie formulovat model odpovede srdcových myocytov na gravitáciu a zmeny zátaže v priebehu vývoja.

\section{Изоляция сердца и кардиогенной зародышевой ткани ранних эмбрионов японской перепелки с целью изучения РНК и генной экспрессии}

Успешно и воспроизводимым способом нами была изолирована общая РНК из небольшого количества ткани сердца эмбрионов японской перепелки (отдельные образцы были от 5 - 25 эмбрионов) с применением триозольного метода для получения РНК. Изолировали РНК приблизительно 150 эмбрионов на разной стадии развития миокарда, включая стадии 2-8, 8-14, 15-19 и 20-34 листков. Нами была также изолирована РНК миокарда приблизительно 400 эмбрионов японской перепелки штамма Иванка 01, селектированной на стойкость к гиподинамии, а именно на стадии развития птичьего сердца. Цель работы сводилась к исследованию влияния притяжения (гипергравитации и ускорения $1 \mathrm{~g}$ ) на экспрессию определенных групп генов в эмбриональном сердце куриц и перепелок. На основе полученных результатов нами будет с использованием клеточной и молекулярной биологии формулирована модель ответа мышечных клеток сердца на притяжение и изменения нагрузки в ходе развития. 


\section{References}

American Society for Gravitational and Space Biology (ASGSB) 1993: Newsletter 9, 13

AUSUBEL, F. M., BRENT, R., KINGSTON, R. E., et al. 1994: Current Protocols in Molecular Biology. Vol. I., Wiley and Sons, New York

BOḊA, K., SABO, V., JURANI, M., GURYEVA, T. S., KOČIŠOVÁ, J., KOŠTÁL, L., LAUKOVÁ, A., DADASHEVA, O. A. 1992: Acta vet. Brno 61: 99-107

GURYEVA, T. S., DADASHEVA, O. A., MELESHKO, G. I., SHEPELEV, Ye. Ya., BODA, K., SABO, V. 1993: Acta vet. Brno, Suppl. 6, 62: S25-S30

HAMBURGER, V., HAMILTON, J.1951: J. Morph. 88: 49-92

HULLINGER, R. L. 1993a: The Physiologist 36: S42-S45

HULLINGER, R. L. 1993b: Acta vet. Brno Suppl. 6, 62: S17-S23

KOMURA, I., YAZAKI, Y. 1993: Ann. Rev. Phys. 55: 55-75

MELESHKO, G. I., SHEPELEV, Ye. Ya., GURYEVA, T. S., BODA, K., SABO, V. 1991: Space Biol. Aerospace Med. 25: 37-39

PADGETT, C. S., IVEY, V. D. 1960: Anat. Rec. 137: 1-11

SABO, V. 1980: Ph. D. Thesis, Institute of Animal Biochemistry and Genetics, Slovak Academy of Sciences, Ivanka pri Dunaji

SAIKI, R. K., BUGAWAN, T. L., HORN, G. T., MULLIS, K. B., EHRLICH, H. A. A. 1986: Nature 324: 136-166 SUGI, Y., SASSE, J., BARRON, M., KOUGH, J. 1995: Developmental Dynamics 202:115-125

SWYNGHEDAUN, B. 1996: Physiol Rev. 66: 710-711 
Andrisani, O.M. et al.: Selection... pp. 51-56.

Plate I.

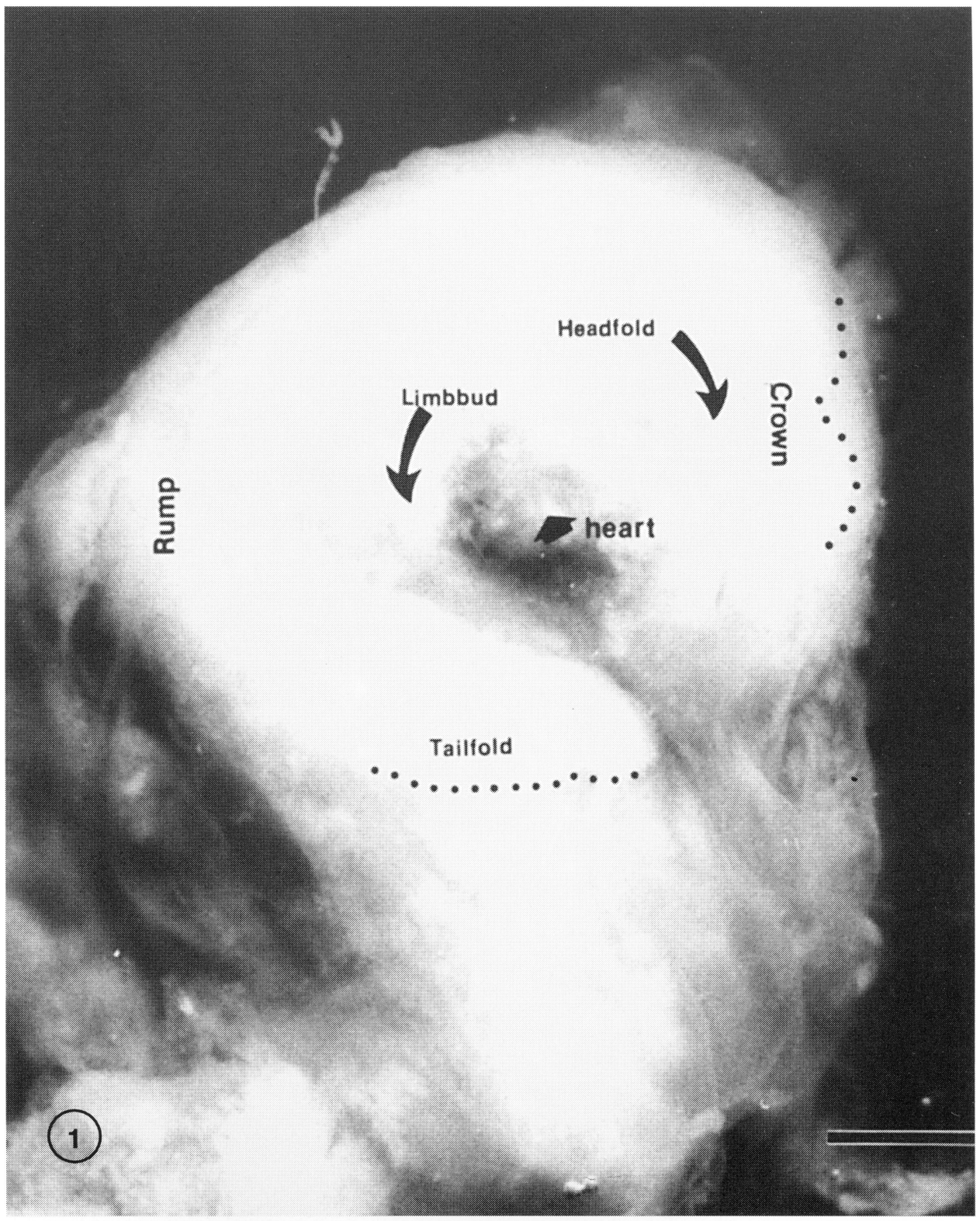


Plate II.

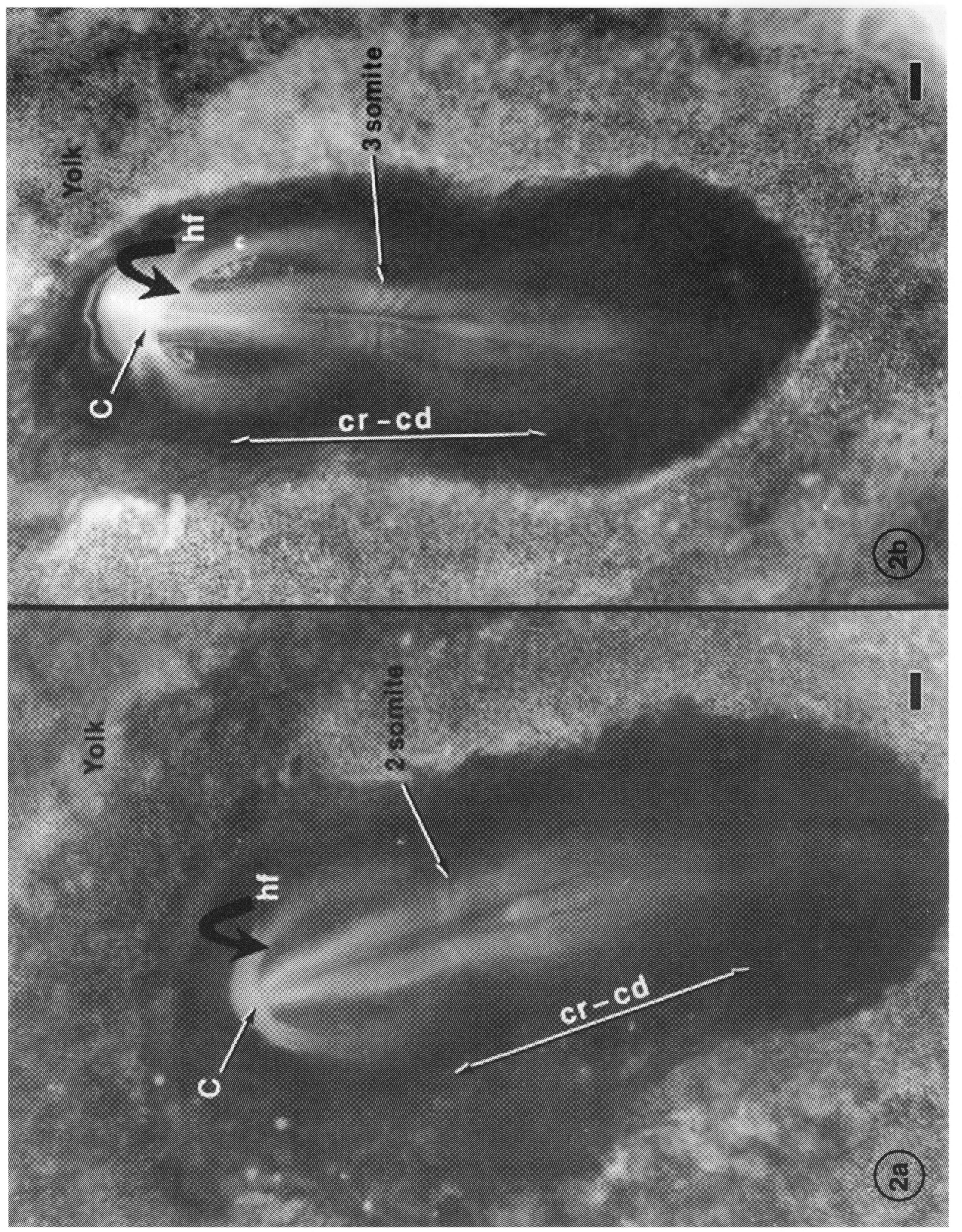




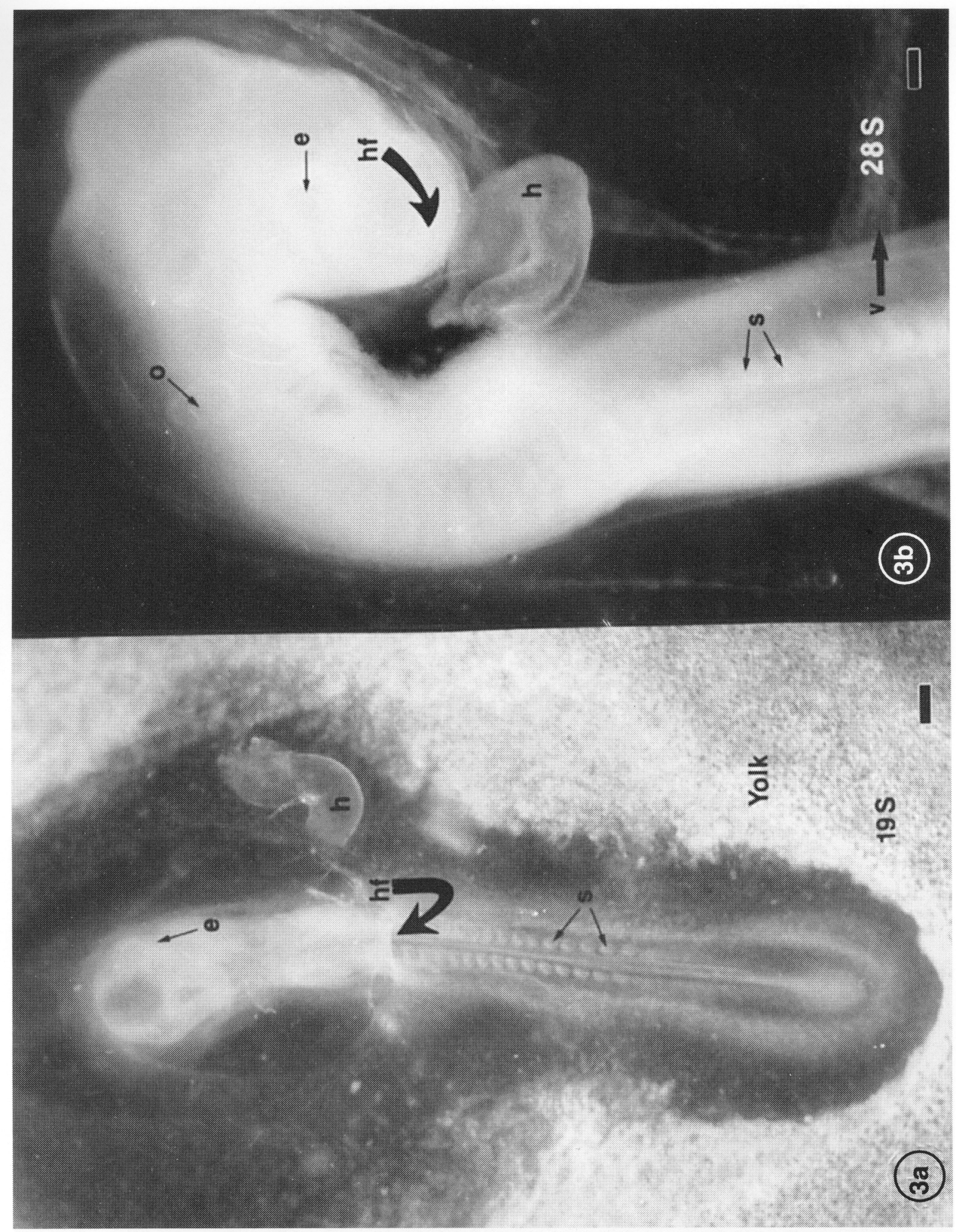


Plate IV.

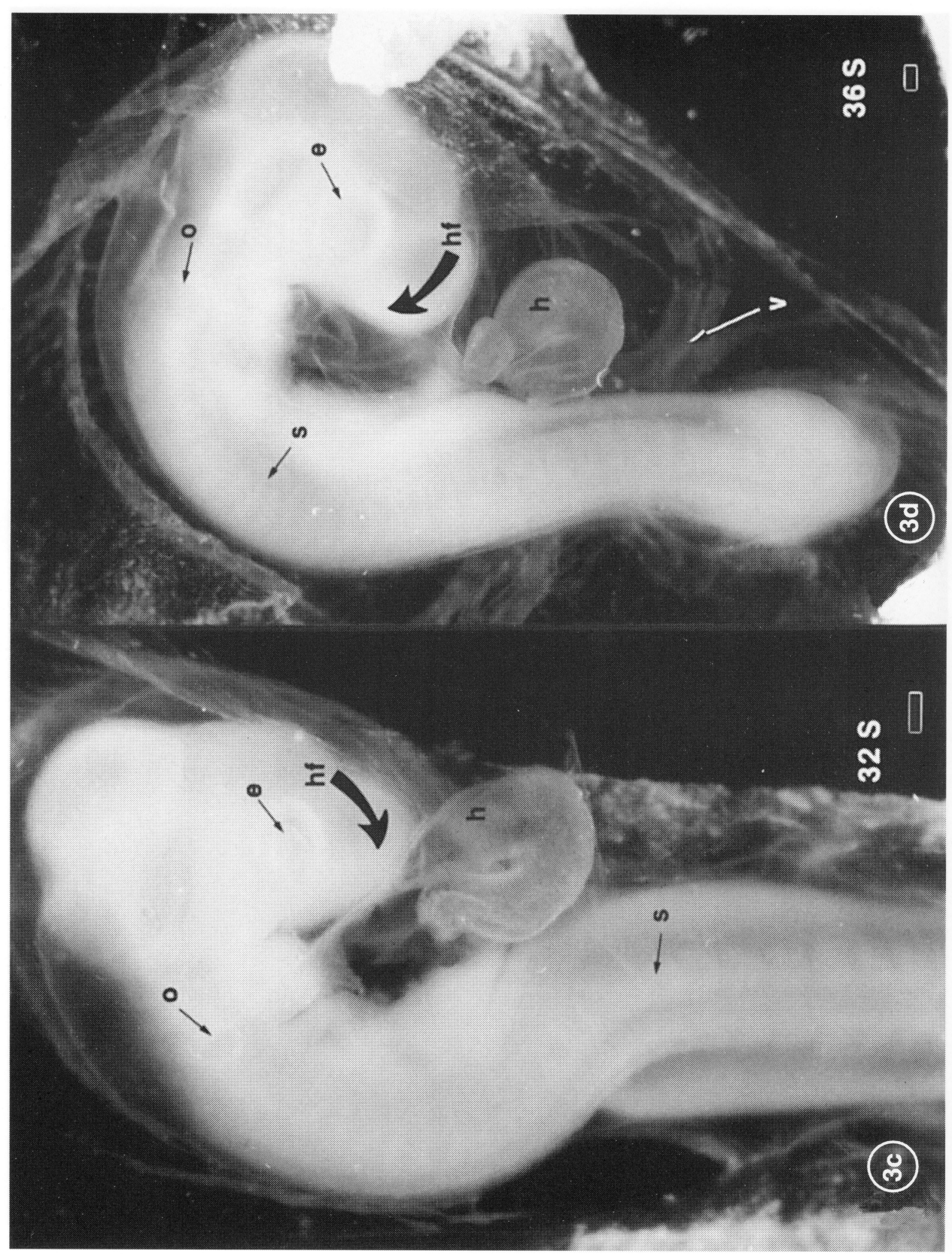


Plate V.
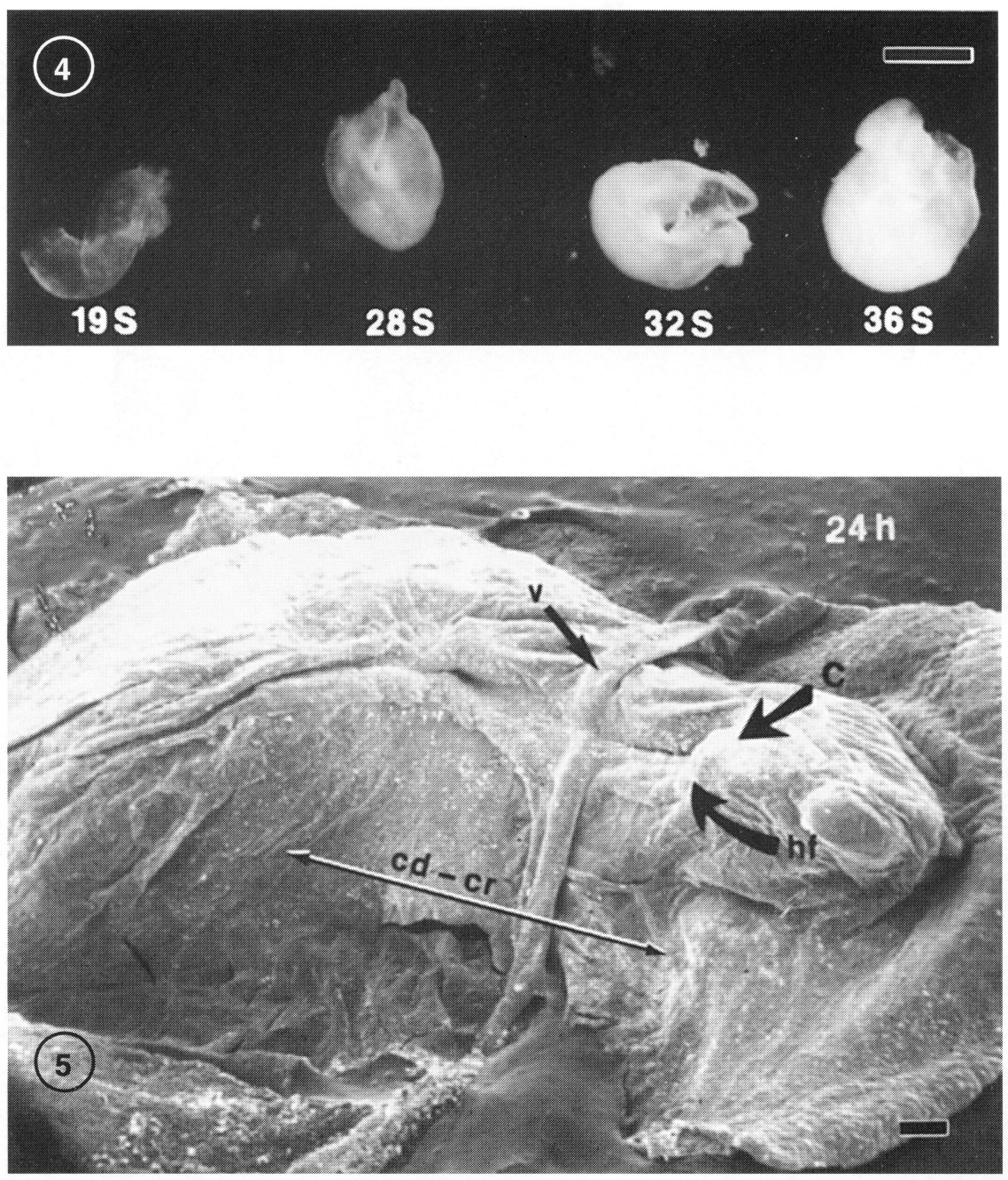
Plate VI.

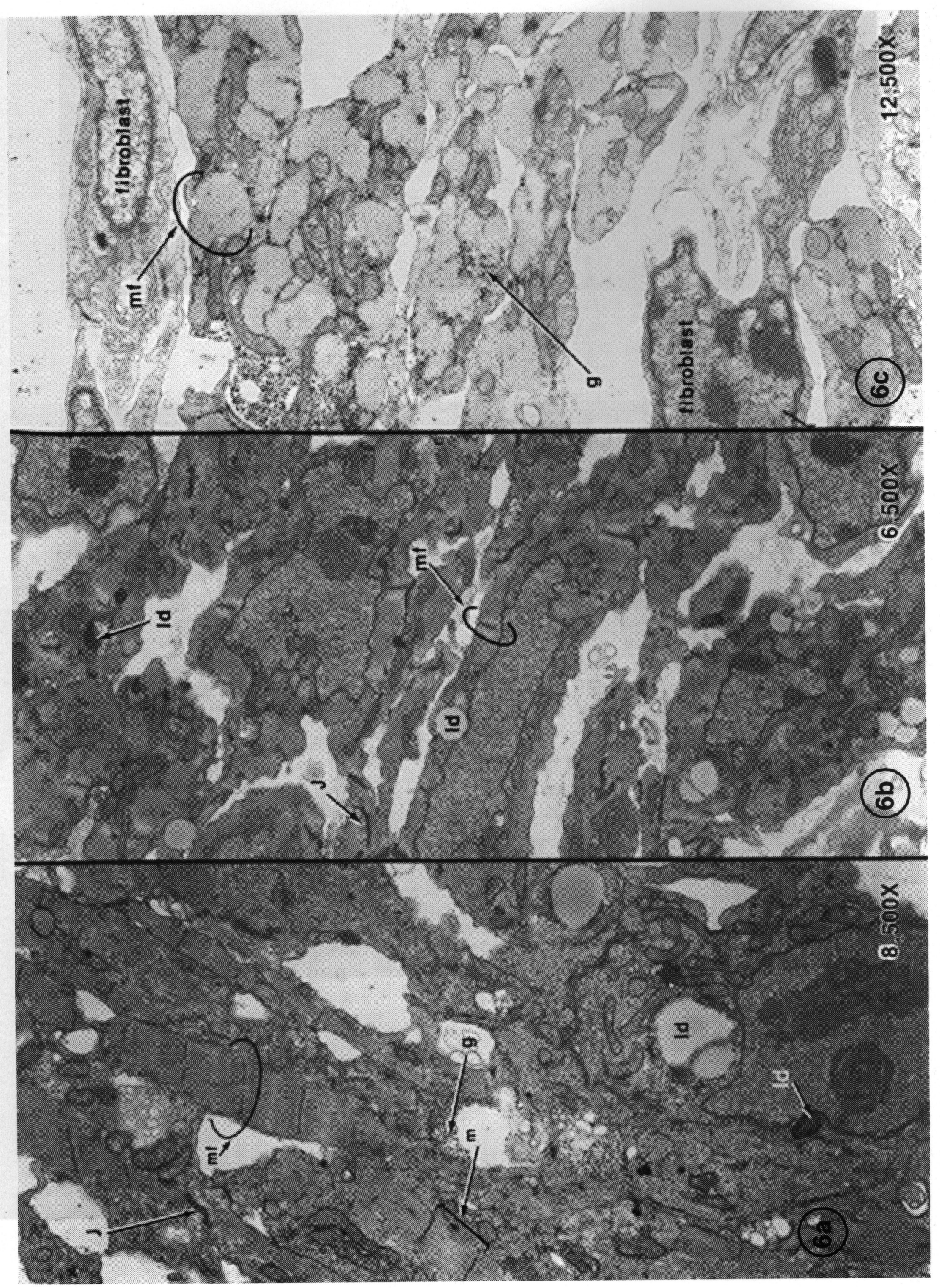




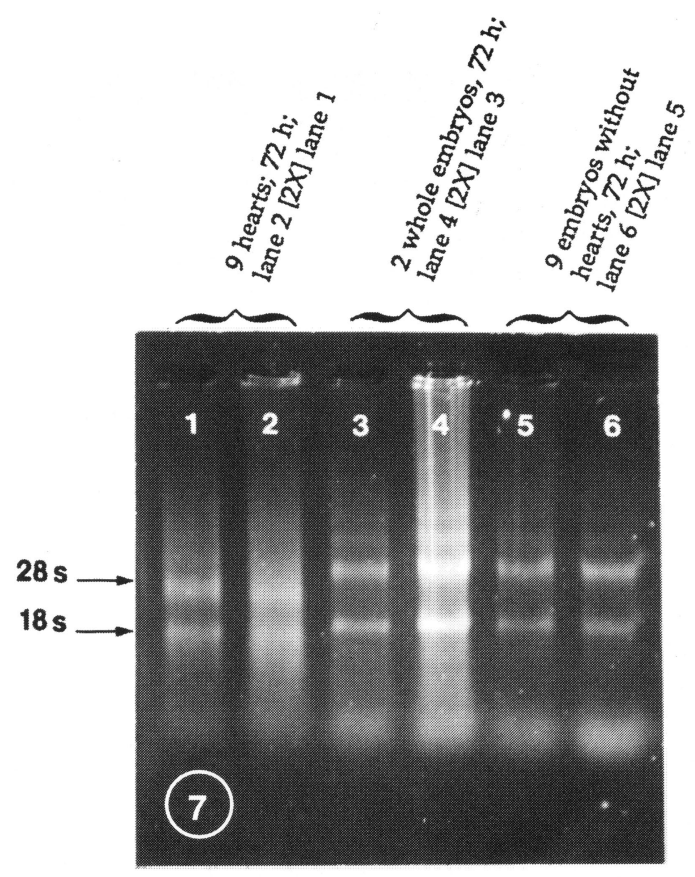

\section{Legends to Fig. 1-7}

Figure 1. Surface features STS-29 flight embryo, domesticated chick, 4-day, i. e., 2 days into the mission, examined at projected hatch day, 14 days after mission. Morphologic criteria for embryo staging were determined by preflight testing of time-developed embryos; criteria were compatible with those published by V. Hamburger and H. L. Hamilton, 1951. Paraformaldehyde fixation, bar $=1 \mathrm{~cm}$.

Figures 2A-B. Japanese quail embryos at 2-somite stage and 3-somite stage, respectively. Arrow indicates cardiogenic mesenchyme (C) near margin of the headfold (hf); somites, yolk, and cranial-caudal axis (cr-cd); 3\% glutaraldehyde, ventral-dorsal view, $\mathrm{bar}=0.5 \mathrm{~mm}$.

Figures 3A-B. Japanese quail embryos at 19 and 28 somite stage, respectively. The heart tubes are labeled (h) and have been dissected free form thorax; they lie adjacent to the headfold (hf). 3A: Ventral-dorsal view, somites (s), yolk; 3B: Dorsal view, head and neck have rotated right to left $90^{\circ}$; somites, otocyst (o), eye (e) vitelline blood vessel (v); $3 \%$ glutaraldehyde, bar $3 \mathrm{~A}=1.0 \mathrm{~mm}, 3 \mathrm{~B}=0.5 \mathrm{~mm}$.

Figures 3C-D. Japanese quail embryos at 32 and 36 somite stage, respectively. The heart tubes are labeled (h) and have been dissected free from thorax; they lie adjacent to the headfold (hf). Note rotation of head and neck, somites (s), otocyst (o), eye (e), vitelline vessel (v); $3 \%$ glutaraldehyde, bar $=0.5 \mathrm{~mm}$.

Figure 4. Japanese quail hearts isolated from embryos 19S, 28S, 32S, and 36S stages, respectively (also shown in Figs. 3A-3D). Note relative size. The heart density changes with myoblast proliferation and differentiation to form myocardium. $3 \%$ glutaraldehyde, bar $=1.0 \mathrm{~mm}$.

Figure 5. Scanning electron photomicrograph of domesticated chicken embryo, 24h. Headfold (hf), cardiogenic primordium (c), cranial-caudal axis (cr-cd), vitelline vessel (v); Trump's fixative, ventral-dorsal view, bar $=0.5 \mathrm{~mm}$.

Figure 6: Transmission electron photomicrograph of Japanese quail myocardial myoblasts. Myoblasts 5A from $72 \mathrm{~h}$ embryo; 5B from 10d embryo; $5 \mathrm{C}$ from $15 \mathrm{~d}$ embryo. Note cellular change in cell density and transformation of shape from reticulated to fusiform. Cells demonstrate typical myofibrils (mf), myomeres (m), lipid droplets (ld), glycogen (g), and cell-cell junctional modifications (J). Trump's fixative, osmium post-fix, staining; $5 \mathrm{~A}=8500 \mathrm{X}$, $\mathrm{B} 5=6500 \mathrm{X}, 5 \mathrm{C}=12,500 \mathrm{X}$.

Figure 7. 1\% agarose-formaldehyde gel electrophoresis of total RNA isolated from 4d Japanese quail embryos: lanes $1 \& 2: 9$ hearts, lanes $3 \& 4: 2$ whole embryos, lanes $5 \& 6: 9$ embryos (from which the hearts were removed). (Lanes 2, 4, and 6 were loaded with $2 \mathrm{X}$ the extract of lanes 1, 3, and 5, respectively.) 